\title{
Correction to: Fingerspitzengefühl
}

\author{
Eric Briys ${ }^{1}$
}

Published online: 27 October 2021

(c) The Geneva Association 2021

\section{Correction to: The Geneva Papers on Risk and Insurance - Issues and Practice https://doi.org/10.1057/s41288-021-00214-w}

The original version of this paper was inadvertently published with an incorrect word in one sentence on page 255 .

The correct sentence is as follows:

Risk aversion kicks in: the less risk averse the insured, the larger the deviation from full insurance, all else being equal.

The original article has been corrected. We apologise for any inconvenience caused to our readers.

Publisher's Note Springer Nature remains neutral with regard to jurisdictional claims in published maps and institutional affiliations.

The original article can be found online at https://doi.org/10.1057/s41288-021-00214-w.

Eric Briys

ericbriys@gmail.com

1 Brussels, Belgium 